\title{
Investigating Students' Collaborative Work to Continue to Use the Social Networking Site
}

\author{
Timothy McBush Hiele ${ }^{1}$, Andree E. Widjaja ${ }^{2}$, Jengchung Victor Chen ${ }^{3}$, Taqwa Hariguna ${ }^{4}$ \\ ${ }^{1}$ Applied Computing Program, Ming Chuan University, Taiwan, mcbush@ mail.mcu.edu.tw \\ ${ }^{2}$ Department of Information System, Universitas Pelita Harapan, Indonesia, andree.widjaja@uph.edu \\ ${ }^{3}$ Institute of International Management, National Cheng Kung University, Taiwan, victor@ mail.ncku.edu.tw \\ ${ }^{4}$ Department of Information System, Universitas Amikom Purwokerto, Indonesia, taqwa@amikompurwokerto.ac.id
}

\begin{abstract}
This study examines the students' online group collaboration using an online social media and social networking site (SNS) - Facebook. The objective of this study is to assess students' group collaborative assignment using the SNS as a platform to share information, ideas, and other related classroom activities. Moreover, this study also assesses the students' intention to continue to use SNS for collaboration and learning activities. A total of 127 students were used as participants in this study. Furthermore, this study employs a PLS-SEM using a SmartPLS software package. The results show that sociability and Facebook quality have significantly influenced perceived effectiveness. Likewise, both sociability and perceived effectiveness are important determinants of satisfaction. In addition, satisfaction positively influences students' attitude to use the Facebook. The results also show that both satisfaction and attitude toward Facebook are significant predictors for students to continue to use the Facebook platform as a tool for online group assessment. Overall, this study sheds light on the importance of students' group collaboration using social networking site platform. This reflects an onus for students to embrace the presence of online social media and social networking sites as the tools for a learning environment.
\end{abstract}

Key words: continuance intention, expectancy disconfirmation theory, perceived effectiveness, sociability, social networking sites

\section{INTRODUCTION}

Social media and social networking sites (SNSs), such as Facebook, Twitter, Instagram, Tumblr, Research Gate, and LinkedIn have evolved and are becoming important tools for learning. These tools can accommodate the propensity of collaboration among individuals. SNS allows members to coordinate and create personal profiles, add and list friends, and retrieve information about others [1]. This signifies that SNS is an important tool to discuss topics and issues, share information and allow collaboration among the members. However, the recent growth of social networking transpired new opportunities not only for socializing but also for knowledge sharing and learning [2]. Indeed, the proliferation of SNS has been one of the most pertinent revelation and has been deeply embedded in the daily routine of individuals. According to [3], social media tools are regarded as powerful drivers of change for teaching and learning practices, which include openness, interactivity, and sociability. The embodiment of social media and SNS has transformed the way in which individuals communicate and do business, and even change the way in which higher education institutions teach their students [4].It is now common in higher education for instructors to utilize social media in order to motivate and challenge their students pertaining to the learning objective [5]. Even students can use the presence of mobile cloud computing services in higher education [6]. Nowadays, many students tend to use SNS to share information, discuss topics or concepts, and collaborate to complete homework assignments [2]. In particular, Facebook, which allows members to participate in a learning environment and can accommodate pedagogic strategies for instructors to organize classroom activities - lecture, homework, assignments, and class participation [7].

According to [8], Facebook is mostly used by college students as a social communication platform. Not only the college students, but educators in general and others are interested in the effects of social media [9]. Moreover, [10] reveals that students use social media in a variety of ways pertaining to their learning in meaningful ways. This symbolizes that social media and social networking sites are important tools for students.

Though Facebook may condones as an informal communication around classroom activities [8], but perhaps may plays an important role for students to use with regard to collaborative activities about classroom-related content. Traditionally, the Internet-based group support system (GSS) is one of the well-known tools for lecturers and students to use in order to participate in the assessment process. GSS has major impacts on students' learning approaches and outcomes [11] However, at present, Facebook becomes an important computer-mediated environment for students to build social connection and tends to be part of their tool to engage in collaborative activities. This is a significant trend where students understand and undertake the role of Facebook from both social and academic perspectives.

A plethora of research has been dedicated to collaborative environment, such as in social media and social networking sites with regard to knowledge sharing and 
learning performance [2], [12], learning outcomes [7], [13], teaching and learning purposes [4], teaching and learning practices [14], online discussions [15], effectiveness of collaborative assessment [11], active collaborative learning and engagement [16], [17], [18], collaborative writing tasks [19], double-edged sword that both helps and hinders learning [10], learning process [20], peer assessment [21], community services practices [22], and self-efficacy [8]. However, this study instead, provides an insight and sheds light on students' continuance intention by using SNS as a platform for collaborative assessment. This study delineates and brings two universities - National Cheng Kung University in Taiwan and Airlangga University in Indonesia through the presence of SNS online applications.

Overall, the fundamental objective of this present study is to assess how students utilize Facebook as a group collaborative platform through which they conduct a group assignment by sharing information, ideas, and other related classroom activities. Last but not the least, this study also assesses the students' intention to continue to use SNS for collaboration and learning activities. This study therefore focuses on evaluating the role of the following variables as antecedents of continuance intention: sociability, Facebook quality, perceived Facebook effectiveness, satisfaction, and attitude toward Facebook.

\section{THEORETICAL FRAMEWORK}

\subsection{Social networking site platform}

Social networking site is a global phenomenon that is emerged due to the significant development and advancement of the information technology. SNS are indeed essential to support interactions, information sharing, and exchanging personal experiences [2]. Undoubtedly, social networking sites and social media are playing a critical role in today's society. [3] highlight that social media tools are the powerful drivers, which offer a wide range of applications to enable users to create, share, comment and discuss digital contents. Moreover, social media are useful tools that can alter the way of pedagogical practices due to its openness, interactivity and sociability [3]. SNS software provides better learning environment that can enhance better interaction and online discussion in comparison to traditional learning management tools [23], [24] . Many students utilize the presence of SNS in order to share information and knowledge and do collaborative homework assignments [2]. This depicts that SNS is an important platform in education.

Despite the growing popularity of the social network sites, such as Twitter, Instagram, Tumblr, Research Gate, and LinkedIn; to date, Facebook has thrived and received considerable attention from many research fields, including social and behavioural sciences, economics and law, business and marketing [25]. [26] revealed that students considered Facebook as an important learning tool that can improve academic collaboration, discussion, and networking. This enables Facebook to become popular and has part and parcel of students' everyday life [27]. Facebook is not only a wellknown SNS but it also acts as a classroom management software tool for a synergetic learning team [28]. According to [13], Facebook has a positive effect on university student's learning impact. Though, Facebook may perceived as an informal system but students have used it as platform to conduct various organizing activities, such as sharing information and collaboration on assignments [8].

On contrary, Facebook may still be considered as a limited and restricted platform for scholars. This is mainly due to several reasons, such as cultural resistance, pedagogical concerns and institutional constrains [25]. Regardless of these limitations, higher education institutions should embrace Facebook as a technology-enhanced learning platform. Facebook can enable students to conduct any collaborative assignments regardless of the location and time zone differences. Higher education institutions should treat Facebook as a learning platform that can enable students to share information, knowledge, and collaborate with classroom activities.

\subsection{Collaborative assessment}

Information and communication technology has transformed the way instructors and students interact and perform classroom activities collectively. According to [29], ICT has been pervaded into instructions within many classrooms and this empowers the variety of pedagogical teaching and learning performances. As a result, ICTs are becoming a ubiquitous tool of classroom learning [8]. Indeed, computer and web-based applications provides an avenue for plenty of opportunities to embrace group learning online environment [30]. Conventionally, computer mediated environment (CME), such as the group support systems are paramount to online pedagogical activities. GSS is an interactive learning environment that integrates computing, communication and digital technologies to enable solution in collaborative work or assessment [11]. The use of GSS is quite effective in enhancing collaborative learning and group assessment. According to [11], assessment is one of the most important process in teaching and learning process. This signifies that through the use of collaborative environment then students' can enhance better collaborative learning process and learning outcomes. The availability of Internetbased GSS has improved the effectiveness of collaborative assessment in which students enhanced deeper approach to learning outcomes [11]. However, with the increasing development of SNSs, these tools are becoming more popular for collaborative assessments. Social network sites represent massive resources for learning and social activities such as participation, interaction and collaboration [14].Facebook, in particular, acts as a learning tool that promotes collaborative learning [26]. According to [31], Facebook can be used as a CME for students to build and promote social connections and also for educational purposes.

Furthermore, a successful learning is based upon collaboration and social rather than isolation and competition [32] This anticipates that a platform, such as Facebook can allow students and others to collaborate and be more proactive to advance learning outcomes. In this regard, the Facebook platform can help students to form a network, collaborate, and share resources with one another for 
educational purposes. Therefore, this study accentuates heavily that students can use Facebook as a key platform for group collaborative assessment.

\subsection{Expectancy disconfirmation theory}

The expectancy disconfirmation theory (EDT) was developed by [33] to assess the consumers' intention to repurchase a product or reuse a service, which is determined by the level of satisfaction. EDT posits that expectations, disconfirmation, and performance are predictors of customer satisfaction. Even though EDT has been used predominantly in the marketing field; however, nowadays this theory has been widely practised in many different fields. Expectancy disconfirmation theory postulates that expectations, disconfirmation, and performance affect customer satisfaction. This portrays that satisfaction is greatly influenced by expectations, disconfirmation, and performance. Moreover, information systems (IS) researchers have begun to apply EDT to explain users' information technology (IT) satisfaction [34], [35]. On the other hand, [36] assert that EDT has been successfully applied to predict users' intention to continue to use IT.

Furthermore, [35] have made it clear that even though IS researchers have adopted EDT, but they often refine the model in order to reduce the EDT's explanatory potential. In this line of argument, this study proposes a decomposed expectancy disconfirmation theory model for continuance intention where sociability, Facebook quality, perceived effectiveness, satisfaction and attitude toward Facebook are crucial predictors. However, [34] highlight a two-stage theoretical model of cognition change, where an IT usage can be distinctively assessed in terms of pre-usage stage and usage stage respectively. By following this logic, this study proposes a decomposed EDT model to investigate cognitive beliefs (sociability, Facebook quality, and perceived Facebook effectiveness) to affect satisfaction, which in turn is jointly determined by attitude toward Facebook to predict users' continuance intention.

\subsection{Hypotheses development}

\subsubsection{Relationship between sociability, perceived} effectiveness, and satisfaction

Sociability is described as the way in which technology facilitates the emergence of a sound social space among group members pertaining to group norms, roles, and beliefs [37], [38]. Moreover, sociability in a functional environment could potentially associate with attributes such as trust and belonging, a strong sense of community and descent working relationships [38]. This portrays that sociability is an important factor that can influence an environment for social interactions. With the presence of a social process in an online environment, a group collaboration is attainable. This is mainly due to IT platform or technological designs that could permit groups to interact and develop social relations among the team members [39]. Sociability is a feature of the IT platform that permits information sharing and task allocation to enhance students' perceived effectiveness and level of satisfaction for virtual team collaboration. In fact, sociability enhances a new approach for collaboration and learning outcomes [40], [41]. The use of social media and social networking sites, such as Facebook are essential for group collaborative learning assessments. The SNS environment encourages students to form informal conversation, social feedback and relationship among the group [39].

Furthermore, the SNS give rise to sociability pertaining to the sound - social space, where students can trust each other and work together in groups cohesively. Through the presence of sociability, students can enhance their level of social affordances; thus, result with higher level of satisfaction. The use of SNS allows students to share information and attain higher sociability that can lead to higher level of satisfaction. In this regard, this study postulates that sociability is a factor, which influences perceived Facebook effectiveness for virtual team collaboration and satisfaction. The greater the level of sociability - social interaction among the students, the greater they will perceive Facebook as an effective environment for learning and will enhance better satisfaction.

Based on the aforementioned literature, this study argues that sociability is an important factor that influence perceived Facebook effectiveness for virtual team collaboration and satisfaction. Therefore, this study proposes the following hypotheses:

H1a: Sociability has a positive and significant influence on perceived effectiveness.

$\mathrm{H} 1 \mathrm{~b}$ : Sociability has a positive and significant influence on satisfaction.

2.4.2. Relationship between Facebook quality, perceived effectiveness, and satisfaction

Past research in IS field has used the IS success quality dimensions (information quality, system quality, and service quality) in various contexts [42], [43], [44], [45], [46], [47],[48], [49], [50], [51]. Quality, in general, is an important factor that can potentially describe or even influence a situation, event, organization and/or person. However, this study emphasizes heavily on the system quality, in regards to the social networking site platform.

A high-quality IT tend to lead to system success [51], [52]. That is, the quality IT can enable standards pertaining to the connectivity, compatibility, and modularity of the hardware, software, and the data in an organization [53]. Similarly, the quality of the SNS environment can influence the effectiveness of the team collaboration. In the context of Facebook, for instance, may serve different purposes such as communicate with one another, make new friends, keep in touch with associates, share information, or discover rumors [54], but it may also serve a team as a whole. Simply, individuals can create and maintain social relationships through the quality functions of Facebook. Hence, a higherquality SNS environment could allow students to perceive the effectiveness of Facebook. Facebook quality, once perceived as useful and effective, and then are more likely for higher education institutions to institutionalize its use. 
On the other hand, the EDT can explain that through disconfirmation then the discrimination of a user's perception of a platform like Facebook quality can meet his or her expectation. In this study, Facebook quality can describe the disconfirmation of a user's perception of the Facebook effectiveness for virtual team collaboration. Prior research apply this similar logic based on the quality and value disconfirmation of a user's perception in regards to the online usability [55]. Moreover, [56] highlight that the quality of the e-learning system significantly influence satisfaction. In this regard, Facebook quality, if utilized meticulously, is likely to enhance students to work together cohesively and collectively, thus, creating an avenue to attain higher level of satisfaction. The high level of Facebook quality in usage may value in a team's collaborative assessments, thus, ultimately attain higher level of students' satisfaction. In light of this line of argument, the inclusion of IT quality is an important antecedent to perceived Facebook effectiveness for virtual team collaboration and satisfaction.

Based on the aforementioned literature, this study argues that high quality IT platform can lead to a system success, and can be perceived as effective and eventually lead to higher level of satisfaction. Therefore, this study proposes the following hypotheses:

H2a: Facebook quality has a positive and significant influence on perceived effectiveness.

$\mathrm{H} 2 \mathrm{~b}$ : Facebook quality has a positive and significant influence on satisfaction.

2.4.3. Relationship between perceived effectiveness and satisfaction

Perceived effectiveness can be associated with characteristics such as efficiency, performance, and motivation. In an online environment, such characteristics are crucial for users to assess the effectiveness of the platform. The effectiveness of the platform will create a high-level of collaborative environment that allows users to attain different purposes such as to keep in touch with friends and family members, share information, and determine how to retrieve useful information. [56] highlight that system quality can effectively enhance better e-learning usefulness. This portrays that the performance of the system must provide and sustain effective performance of the system in order to meet users' expectation, thus may eventually result with higher level of satisfaction. According to EDT, disconfirmation is influenced by expectations and perceived performance; hence, once the positive disconfirmation is achieved, then a user will be satisfied. According to [57], perceived performance is positively related with expectation congruency, in regard to camcorder usage. Likewise, the performance of the Facebook platform will allow students to sustain their expectation congruency, especially when collaborating for a group assessment. The effectiveness of the Facebook is paramount to students' expectation and level of satisfaction.

Based on the aforementioned literature, this study argues that the effectiveness of social networking site environment will enable teams to coordinate with one another to meet ones' expectation, and will ultimately lead to influence students' satisfaction. Specifically, this study postulates that the perceived Facebook effectiveness for a virtual team collaboration may lead to have impact on enabling higher level of satisfaction. Therefore, this study proposes the following hypothesis:

H3: Perceived effectiveness has a positive and significant influence on satisfaction.

2.4.4. Relationship between satisfaction, attitude toward Facebook, and continuance intention

A plethora of research has been done extensively to investigate the relationship between satisfaction and attitude toward IT usage [34], as well as the relationship between satisfaction and continuance intention [58], [59], [60], [61], [55], [62], [63], [64], [65], [66], [67], [68] . However, Bhattacherjee and Premkumar (2004) proposed an IS usage model for pre-usage stage and usage stage, where satisfaction is critical to understanding changes in IT users' attitudes and intention to IT usage. Based on the EDT perspective, users' perception about the IT usage and satisfaction with a system are essential to their attitude toward the system and their continuance intention. [33] postulates that satisfaction is positively correlated with intention through the direct or indirect presence of attitude. Hence, satisfaction is indeed a significant predictor on attitude and that may continue to recur over time as users gain additional IT usage [34].

Moreover, users' intention to continue to use an elearning service is paramount to e-learning success [36]. Similarly, SNS users can depend toward understanding its environment and then eventually assess its success for continuance intention to use in the future.

Based on the aforementioned literature, this study postulates that satisfaction will have a favourable impact on attitude toward Facebook usage and continuance intention to use Facebook in the future. Therefore, this study proposes the following hypotheses:

H4: Satisfaction has a positive and significant influence on attitude toward Facebook.

H5: Satisfaction has a positive and significant influence on continuance intention.

2.4.5. Relationship between attitude toward Facebook and continuance intention

Prior research on technology acceptance model (TAM) and theory of planned behaviour (TPB) has investigated the relationship between attitude and IT usage intention [69], [70], [71], [72], [73], [74], [75]. In essence, the attitude towards use is an important predictor of the behavioral intention to use a system [72]. [56] highlights that users' attitude toward e-learning encourages the creation of suitable e-learning environment for learning processes. This depicts that the attitude towards IT use is critical to influence students' intention to reuse the online system during the learning process. Specifically, in this study, the students' attitude toward using Facebook as a tool for collaborative 
Timothy McBush Hiele et al., International Journal of Advanced Trends in Computer Science and Engineering, 8(1.5), 2019, 375- 386

assessment is a key factor to have impact on their continuance intention to use Facebook.

Based on the aforementioned literature, this study postulates that students' favourable attitude to use Facebook will positively influence their continuance intention to use the Facebook in the future. Therefore, this study proposes the following hypothesis:

H6: Attitude toward Facebook has a positive and significant influence on continuance intention.

\section{RESEARCH METHOD}

\subsection{Research framework and construct measurements}

Figure 1 shows the research model of this present study. This study operationalizes the following variables sociability, Facebook quality, perceived effectiveness, satisfaction, attitude toward Facebook, and continuance intention. The measurement items for sociability were adopted from previous research[39],[38]. Similarly, Facebook quality is operationalized based on the measurement items adopted from prior research [51], [36]. Perceived effectiveness, on the other hand, is operationalized by following the measurement items from prior research [56]. The measurement items for satisfaction were mainly adopted from [36], whilst the measurement items for attitude toward Facebook were adopted from [75]. Last but not the least, continuance intention is measured using the measurement items that were adopted from prior research [36].The questionnaire items were measured using a 7-Point Likert scale (from $1=$ strongly disagree to $7=$ strongly agree).

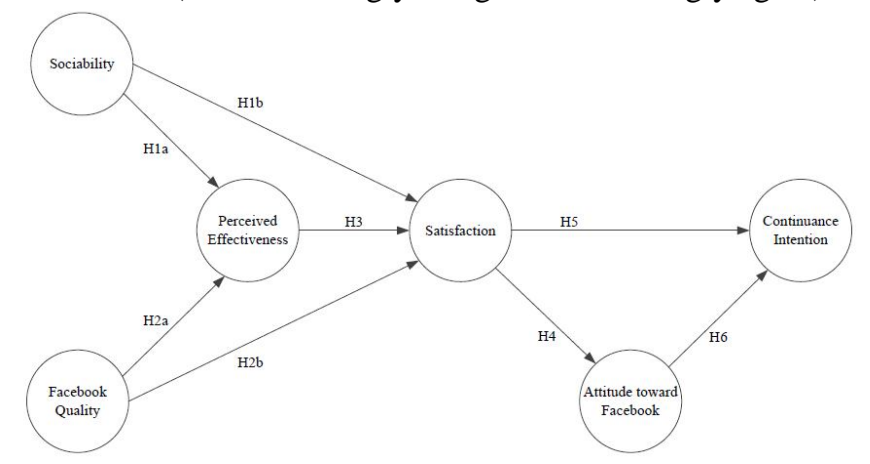

Figure 1: Research model

\subsection{Research setting}

This study aims to study the teams' collaborative efforts between two universities - National Cheng Kung University in Taiwan and Airlangga University in Indonesia. At first, the two professors from both universities agreed, planned, and implemented the group project with help of the Teaching Assistants (TAs). The TAs then created a Facebook account namely "NckuUnair", which is dedicated entirely for the group project collaboration. Once the students added the NckuUnair Facebook account, the TAs then randomly assigned each student into 28 groups. These groups are set privately with only the group members can access and administer the Facebook group page. The TAs monitored all the activities in each group to make sure that all the announcements and tasks are delivered privately.

Furthermore, the TAs announced the group project collaboration based on the following introduction and objective. The announcement of the group assignment is read as follow:

Problem introduction: Recently Facebook has been used to sell some products or services. The new term so called "Facebook Commerce" is emerged. Obviously, all Facebook users can do the business by using Facebook platform. There is increasing trend of Facebook Commerce, however, Facebook users may concern about their privacy and trust both towards the seller and buyer.

In responding to this issue, your team is recruited by the Facebook owner, Mark Zuckerberg, to solve the Facebook commerce privacy and trust.

Objective: Please work Together with your team to propose how to mitigate the privacy concerns in Facebook commerce, so that both sellers and buyers would be more trusted while doing Facebook commerce activities.

You are supposedly to discuss and use various tools provided on Facebook - chatting, comments, videos, etc. Extra points will be given if you and your team members are actively using Facebook group to collaborate.

The grading criteria will be assessed as:

1. Ideas or solutions proposed

2. The quality and reasoning of the ideas/solutions/arguments

3. Clarity of the writings

Submission: The paper should be typed neatly in A4 Word file. There is no page limitation and one group member should upload the paper in your Facebook group

Questionnaire: A survey questionnaire pertaining to this assignment will be administered after paper submission. All students have to fill the online questionnaire, otherwise your submission will be considered incomplete.

Once the students have completed the online questionnaire survey then TAs cross-checked with the responses and reported it to the professors in both universities. Finally, the questionnaire items were analysed by using the SmartPLS 3.0 software package[76].

\section{RESULTS}

\subsection{Demographic results}

Table 1 shows the demographic characteristics of the 127 respondents who were participated in the group collaborative assignment by using Facebook. About 57.5\% of the respondents were students from Airlangga University whereas $42.5 \%$ from National Cheng Kung University. Obviously, the majority of the respondents were females with $61.4 \%$ whereas $38.6 \%$ were males. Furthermore, there was nearly a fair number of students undertaking bachelors and masters with $48.8 \%$ and $49.6 \%$ respectively. As expected, most of the students were full-time students 
Timothy McBush Hiele et al., International Journal of Advanced Trends in Computer Science and Engineering, 8(1.5), 2019, 375- 386

(70.9\%) compared to part-time students (29.1\%). Finally, at least, the students were coming from 16 different countries. Most of these students were from Indonesia, followed by Vietnam as well as from Taiwan and Thailand.

Table 1: Demographic characteristics ( $\mathrm{N}=127)$

\begin{tabular}{|c|c|c|c|}
\hline Demographics & Category & Frequency & $\begin{array}{l}\text { Percentage } \\
(\%)\end{array}$ \\
\hline & $\begin{array}{l}\text { Airlangga } \\
\text { University }\end{array}$ & 73 & 57.5 \\
\hline University & $\begin{array}{l}\text { National } \\
\text { Cheng Kung } \\
\text { University }\end{array}$ & 54 & 42.5 \\
\hline Gender & $\begin{array}{l}\text { Female } \\
\text { Male }\end{array}$ & $\begin{array}{l}78 \\
49\end{array}$ & $\begin{array}{l}61.4 \\
38.6\end{array}$ \\
\hline \multirow{2}{*}{$\begin{array}{l}\text { Level of } \\
\text { Education }\end{array}$} & Bachelor & 62 & 48.8 \\
\hline & $\begin{array}{l}\text { Masters } \\
\text { Ph.D. }\end{array}$ & $\begin{array}{c}63 \\
2\end{array}$ & $\begin{array}{c}49.6 \\
1.6\end{array}$ \\
\hline \multirow[t]{2}{*}{ Student Status } & Full-time & $\begin{array}{l}90 \\
37\end{array}$ & 70.9 \\
\hline & $\begin{array}{l}\text { Part-time } \\
\text { Croatian }\end{array}$ & $\begin{array}{c}37 \\
1\end{array}$ & $\begin{array}{c}29.1 \\
0.8\end{array}$ \\
\hline \multirow{15}{*}{ Country } & Dutch & 2 & 1.6 \\
\hline & Finnish & 1 & 0.8 \\
\hline & German & 1 & 0.8 \\
\hline & Guatemalan & 3 & 2.4 \\
\hline & Honduran & 1 & 0.8 \\
\hline & Indonesian & 75 & 59.1 \\
\hline & Nepali & 1 & 0.8 \\
\hline & Polish & 3 & 2.4 \\
\hline & Russian & 1 & 0.8 \\
\hline & $\begin{array}{l}\text { Solomon } \\
\text { Islander }\end{array}$ & 1 & 0.8 \\
\hline & Swedish & 1 & 0.8 \\
\hline & Taiwanese & 10 & 7.9 \\
\hline & Thai & 10 & 7.9 \\
\hline & $\begin{array}{l}\text { United } \\
\text { States }\end{array}$ & 1 & 0.8 \\
\hline & Vietnamese & 15 & 11.8 \\
\hline
\end{tabular}

\subsection{Measurement model analysis}

To perform the confirmatory factor analysis (CFA), reliability and validity tests, this study follows the thresholds from prior research [77]. Previous research assessed the CFA in order to ensure the reliability of the indictors or items [77], [78]. According to Hair et al. (2013), the PLS-SEM indicator's outer loadings should be at least higher than 0.70 . Any item that is less than 0.70 should be deleted. Based on the CFA results, only two items for sociability were deleted since they are lower than the 0.70 threshold. Table 2 demonstrates all the items for each construct.

Moreover, the composite reliability, average variance extracted (AVE), and Cronbach's alpha were assessed to ensure that there is an internal consistency reliability among the given construct. All of the research constructs have met the given thresholds as suggested by Hair et al. (2013): AVE $\geq 0.5$, composite reliability $\geq 0.70$, and Cronbach's alpha $\geq$ 0.70 . Table 2 also presents the reliability results.
Table 2: Measurement model results

\begin{tabular}{|c|c|c|c|c|c|}
\hline $\begin{array}{l}\text { Construc } \\
\text { ts }\end{array}$ & $\begin{array}{l}\text { Indicat } \\
\text { ors }\end{array}$ & $\begin{array}{l}\text { Standa } \\
\text { rd } \\
\text { Loadi } \\
\text { ngs } \\
\end{array}$ & $\begin{array}{c}\text { Cronbac } \\
\text { h's } \\
\text { Alpha }\end{array}$ & $\begin{array}{l}\text { Compo } \\
\text { site } \\
\text { Reliabil } \\
\text { ity } \\
\end{array}$ & $\begin{array}{c}\mathbf{A V} \\
\mathbf{E}\end{array}$ \\
\hline \multirow{8}{*}{$\begin{array}{l}\text { Sociabilit } \\
\mathrm{y}\end{array}$} & SO1 & 0.778 & \multirow{8}{*}{0.923} & \multirow{8}{*}{0.937} & \multirow{8}{*}{$\begin{array}{l}0.6 \\
53\end{array}$} \\
\hline & $\mathrm{SO} 2$ & 0.777 & & & \\
\hline & $\mathrm{SO} 3$ & 0.786 & & & \\
\hline & $\mathrm{SO} 4$ & 0.894 & & & \\
\hline & SO5 & 0.876 & & & \\
\hline & SO6 & 0.843 & & & \\
\hline & SO7 & 0.710 & & & \\
\hline & SO9 & 0.784 & & & \\
\hline \multirow{8}{*}{$\begin{array}{l}\text { Facebook } \\
\text { Quality }\end{array}$} & FQ1 & 0.842 & \multirow{8}{*}{0.929} & \multirow{8}{*}{0.942} & \multirow{8}{*}{$\begin{array}{l}0.6 \\
70\end{array}$} \\
\hline & $\mathrm{FQ} 2$ & 0.745 & & & \\
\hline & FQ3 & 0.870 & & & \\
\hline & FQ4 & 0.865 & & & \\
\hline & FQ5 & 0.732 & & & \\
\hline & FQ6 & 0.820 & & & \\
\hline & FQ7 & 0.800 & & & \\
\hline & FQ8 & 0.860 & & & \\
\hline \multirow{4}{*}{$\begin{array}{l}\text { Perceived } \\
\text { Effective } \\
\text { ness }\end{array}$} & PE1 & 0.951 & \multirow{4}{*}{0.946} & \multirow{4}{*}{0.961} & \multirow{4}{*}{$\begin{array}{c}0.8 \\
61\end{array}$} \\
\hline & PE2 & 0.934 & & & \\
\hline & PE3 & 0.958 & & & \\
\hline & PE4 & 0.867 & & & \\
\hline \multirow{2}{*}{$\begin{array}{l}\text { Satisfacti } \\
\text { on }\end{array}$} & SF1 & 0.926 & \multirow{2}{*}{0.808} & \multirow{2}{*}{0.912} & \multirow{3}{*}{$\begin{array}{l}0.8 \\
39\end{array}$} \\
\hline & SF2 & 0.905 & & & \\
\hline \multirow{3}{*}{$\begin{array}{l}\text { Attitude } \\
\text { toward } \\
\text { Facebook }\end{array}$} & AF1 & 0.919 & \multirow{3}{*}{0.946} & \multirow{3}{*}{0.961} & \\
\hline & AF2 & 0.925 & & & \multirow{3}{*}{$\begin{array}{c}0.8 \\
60\end{array}$} \\
\hline & $\begin{array}{l}\text { AF3 } \\
\text { FF4 }\end{array}$ & 0.933 & & & \\
\hline \multirow{3}{*}{$\begin{array}{l}\text { Continua } \\
\text { nce } \\
\text { Intention }\end{array}$} & $\begin{array}{l}\mathrm{AF} 4 \\
\mathrm{CI} 1\end{array}$ & $\begin{array}{l}0.933 \\
0.970\end{array}$ & \multirow{3}{*}{0.960} & \multirow{3}{*}{0.974} & \\
\hline & CI2 & 0.970 & & & \multirow{2}{*}{$\begin{array}{l}0.9 \\
26\end{array}$} \\
\hline & $\mathrm{CI} 3$ & 0.947 & & & \\
\hline
\end{tabular}

On the other hand, the Fornell-Larcker Criterion is performed to assess the discriminant validity test. Table 3 shows the results of the discriminant test. As [77] highlighted, the standard loadings for each construct should be higher than all of its cross loadings with other constructs, as well as the square root of the AVE should higher than its highest correlations in comparison to other constructs. The results, however, show that each construct is distinctly discriminant from one another, providing support for the discriminant validity results.

Table 3: Discriminant validity results

\begin{tabular}{ccccccc}
\hline $\begin{array}{c}\text { Construct } \\
\mathbf{s}\end{array}$ & AF & CI & FQ & PE & SF & SO \\
\hline AF & 0.92 & & & & & \\
& 8 & & & & & \\
CI & 0.71 & 0.962 & & & & \\
& 8 & & & & & \\
FQ & 0.62 & 0.567 & 0.818 & & & \\
& 2 & & & & & \\
PE & 0.79 & 0.725 & 0.535 & 0.928 & & \\
& 5 & & & & & \\
SF & 0.76 & 0.745 & 0.563 & 0.850 & 0.916 & \\
& 6 & & & & & \\
SO & 0.73 & 0.569 & 0.546 & 0.675 & 0.711 & 0.808 \\
\hline
\end{tabular}


Timothy McBush Hiele et al., International Journal of Advanced Trends in Computer Science and Engineering, 8(1.5), 2019, 375- 386

Note: $\mathrm{AF}=$ Attitude toward Facebook; $\mathrm{CI}=$ Continuance

Intention; FQ = Facebook Quality; PE = Perceived

Effectiveness; $\mathrm{SF}=$ Satisfaction; $\mathrm{SO}=$ Sociability

\subsection{PLS-SEM results}

This study uses the PLS algorithm in the SmartPLS version 3.0 [76] in order to assess the path coefficient $(\beta)$ value in the research model. However, the bootstrapping method was set to a re-sampling size of 5000, and the PLS path analysis results were generated. This study adopts the recommendation from [77]), and also anticipates the following criteria: the structural parameter at significance level of $p \leq 0.05$ (two-tails test) and $t$-value $\geq 1.96$. Figure 2 shows the overall PLS path analysis results. Based on results, the overall model shows the coefficient of determination $\left(\mathrm{R}^{2}\right)$ as follow: The $\mathrm{R}^{2}$ on perceived effectiveness $=0.495$, satisfaction $=0.763$, attitude toward Facebook $=0.587$ and continuance intention $=0.608$. These results signify that the model fits the data; hence, the overall model fit is acceptable.

Furthermore, the PLS-SEM results are as follow: First, the path coefficient in the relationship between sociability and perceived effectiveness is significant $\left(\beta=0.545^{* * *}, t\right.$ value $=4.305, p=0.000$ ), therefore, hypothesis $1 \mathrm{a}$ is supported. Similarly, the relationship between sociability and satisfaction is significant $\left(\beta=0.221^{*}, t\right.$-value $=2.928, p=$ 0.003 ), therefore, hypothesis $1 \mathrm{~b}$ is supported. Second, the relationship between Facebook quality and perceived effectiveness is significant $\left(\beta=0.238^{*}, t\right.$-value $=2.210, p=$ 0.027 ), therefore hypothesis $2 \mathrm{a}$ is supported. On the contrary, the path coefficient in the relationship between Facebook quality and satisfaction is insignificant $(\beta=0.095, t$-value $=$ $1.373, p=0.170$ ), therefore, hypothesis $2 b$ is not supported. Third, the relationship between perceived effectiveness and satisfaction is significant $\left(\beta=0.650^{* * *}, t\right.$-value $=9.422, p=$ 0.000 ), therefore, hypothesis 3 is supported. Fourth, the relationship between satisfaction and attitude toward Facebook is significant $\left(\beta=0.766^{* * *}, t\right.$-value $=22.313, p=$ 0.000 ), therefore, hypothesis 4 is supported. Likewise, the path coefficient in the relationship between satisfaction and continuance intention is significant $\left(\beta=0.472^{* *}, t\right.$-value $=$ $4.727, p=0.000$ ), therefore, hypothesis 5 is supported. Last but not the least, the path coefficient in the relationship between attitude toward Facebook and continuance intention is significant $\left(\beta=0.356^{* *}, t\right.$-value $\left.=3.422, p=0.001\right)$, indicating that hypothesis 6 is supported.

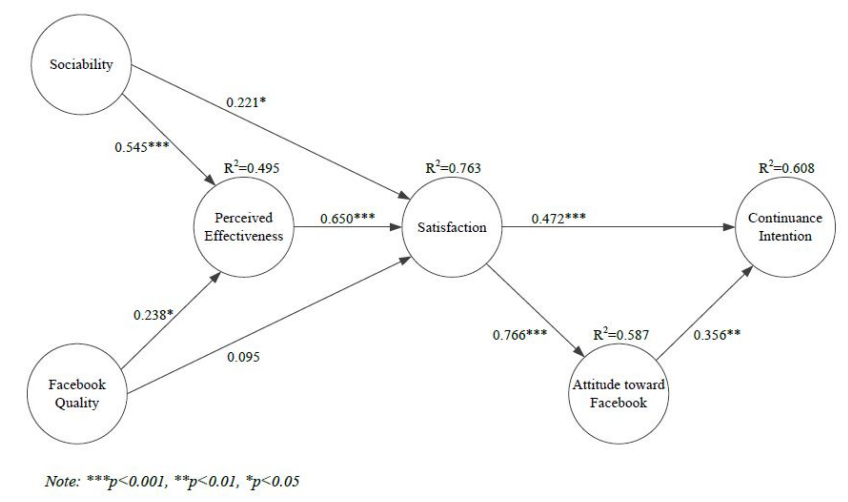

Figure 2: PLS-SEM Results

\section{DISCUSSION}

This study provides empirical evidence by using the expectancy disconfirmation theory to assess the group collaborative assignment on Facebook social networking site. Moreover, this study highlights the results as the following: First, the impact of sociability on perceived effectiveness and satisfaction is well acknowledged for a virtual team collaboration in the online SNS setting. This portrays that having a more social application permits the team to assert greater sense of togetherness and build team cohesively [39]. Students seem to ratify the process of collaboration through the SNS platform, as they are more agreeable to work on the assignments collectively. While students did not only enhance sociability pertaining to the sound - social space, where they have a sense of belongingness to perceive Facebook effectiveness as valuable for virtual team collaboration, but they are satisfied with the process as well. Sociability affects the learning process of virtual team collaboration. This explains that the design of the SNS platform influences the students' virtual team collaboration level of satisfaction.

Second, the results show that Facebook quality influences perceived effectiveness in a virtual team collaboration. This is a revelation that a high-quality IT may lead to a system success [5], [52] with reference to the attributes such as connectivity, compatibility, and modularity of the hardware, software, and the data in an organization [53]. Facebook quality is an essential factor that can influence students' perception to do their collaborative assignment together in a cohesive manner. On the contrary, Facebook quality does not significantly influence satisfaction. One plausible explanation may stem from the nature of Facebook, as it is not a formal system implemented and endorsed by the University, but rather a commercial platform that students use for social purposes [79]. As a matter of fact, Facebook remains ubiquitous for students and its use for formal academic purposes remains unclear [4]. Therefore, the SNS setting and quality may not satisfy the students' collaborative effort at this stage. Despite SNSs are used for educational purposes, there are still tensions and practical challenges to overcome [14]. One way to mitigate the challenges is to make progress and change the mind set among the students through the process of re-education that would allow students to undertake collaborative approaches to learning and knowledge creation in SNS environment [4]. Inevitably, social media and social networking sites represent a new pedagogical dilemma but simultaneously enhance potential for learning [14]. In this regard, instructors and students should rather embrace SNS for teaching and learning purposes.

Third, the results imply that perceived Facebook effectiveness for virtual team collaboration influences satisfaction. Such evidence implies that Facebook can be used effectively for team collaborative assessment. Once students utilize the presence of Facebook in an effective fashion, then there is a tendency for them to achieve higher level of satisfaction. Students can perform effectively when the system quality is guaranteed, and this can lead to a better e-learning usefulness [56]. In light with this argument, the effectiveness of Facebook platform allows students to sustain 
their level of expectation congruency, pertaining to their group collaborative assessment, which is crucial for their learning expectations and ultimately satisfaction.

Fourth, the results show that satisfaction is an important antecedent to both attitude toward Facebook and continuance intention. Such empirical evidence is consistent with the results from previous studies that satisfaction positively influences attitude toward IT usage [34] and continuance intention [58], [59], [59], [60], [61], [62], [63], [64], [65], [66], [67], [68]. It is imperative for students to feel satisfied with their group collaborative assignment on Facebook social networking site in order to perceive their attitude toward such learning environment. This study also reaffirms and reflects that a positive level of satisfaction with regard to the performance and experience of using Facebook as a collaborative environment platform will enhance students to affect their continuance intention.

Finally, the results demonstrate that attitude toward Facebook positively influences continuance intention. Consistent with prior research [69], [70], [71], [72], [73], [74], [75]. This study confirms that a positive students' attitude toward using Facebook as a collaborative environment platform will enable them to continue to use Facebook for learning purposes. The way students use Facebook can pave ways in developing a collaborative learning environment for higher education institutions. With the right learning approach and proper designated module instructions, students will continue to Facebook as a tool for learning.

\section{Conclusion}

This present study has demonstrated that the importance of group collaborative assignment on Facebook social networking site. It is important to note that social networking sites enhance students to share information and work collectively in order to improve their learning outcomes. Students are willing to use SNS, such as Facebook; thus, will continue to use such tool for their learning process. Moreover, this study provides some implications for researchers and practitioners.

First, this study extends the expectancy disconfirmation theory, which was pioneered by [33] to investigate the students' continuance intention to use Facebook social networking site. The results highlight that sociability and Facebook quality are important antecedents to perceived effectiveness. Moreover, the original EDT posits that expectations, disconfirmation, and performance are critical predictors of satisfaction; however, this study demonstrates and supports that sociability and perceived effectiveness are predictors of satisfaction. Drawing upon the results, satisfaction should always be considered as an important predictor of attitude toward IT usage and continuance intention in this EDT perspective. Second, this study contributes to promoting SNS as an important platform for students' collaborative assignment. Especially considering the distance, time, and resources, higher education institutions should start implementing SNS platforms for instructors and students formal learning purposes. The empirical evidence of this study reveals that
SNS - Facebook is a valuable tool for a team collaborative environment platform. Students can foster social interaction as well as considering the quality of Facebook to engage in delivering educational goals. Facebook is useful in creating a learning environment for both instructors and their students [7].Therefore, higher education institutions should make efforts to promote courses via the SNS, thus will reduce costs and utilize resources profoundly. It would be wise to integrate the use of SNS for online collaboration, discussion and learning. Moreover, this study offers a plausible implication to higher education institutions that once students perceive the use of SNS and become satisfy, then they will ultimately continue to use the platform in the near future. Overall, the rise in popularity of SNS for learning purposes will continue to be garnered much attention from both educators and practitioners worldwide.

On the other hand, it is important to assess the study's contributions in light of its limitations; therefore, this study has some limitations. First, the sample size is relative small and may potentially limit the generalizability of the findings to a general audience. This also contributes to the fact that the students are mostly from the business and management field. Future research should consider a wide spectrum of students from different colleges. Second, this study may overlooked some underlying mechanisms that online social networking sites are not easy to monitor and control; therefore, the instructors and teaching assistants might find it difficult to evaluate the work of the students cohesively. Therefore, future research should apply some control measures; for instance, conduct an experimental study instead.

This study also recommends some additional work for future research. First, future research should consider satisfaction as a mediating variable - to mediate the relationship between sociability and continuance intention, as well as the relationship between Facebook quality and continuance intention. Last but not the least, future research on online SNS should find ways to determine the best possible ways to measure the indices of actual behavior of the students as the dependent variable. Such measurement will provide more implications on how students utilize the presence of Facebook for a group collaborative assignment.

\section{REFERENCES}

1. Danah, M. B., \& Nicole, B. E. (2007). Social network sites: Definition, history, and scholarship. Journal of Computer-Mediated Communication, 13(1), 210230. https://doi.org/10.1111/j.1083-6101.2007.00393.x

2. Eid, M. I. M., \& Al-Jabri, I. M. (2016). Social networking, knowledge sharing, and student learning: The case of university students. Computers \& Education, 99, 14-27.

3. Manca, S., \& Ranieri, M. (2016). Facebook and the others. Potentials and obstacles of Social Media for teaching in higher education. Computers \& Education, 95, 216-230. 
4. Donlan, L. (2014). Exploring the views of students on the use of Facebook in university teaching and learning. Journal of Further and Higher Education, 38(4), $572-588$.

5. Waycott, J., Thompson, C., Sheard, J., \& Clerehan, R. (2017). A virtual panopticon in the community of practice: Students' experiences of being visible on social media. The Internet and Higher Education, $35,12-20$.

6. Arpaci, I. (2019). A hybrid modeling approach for predicting the educational use of mobile cloud computing services in higher education. Computers in Human Behavior, 90, 181-187. https://doi.org/10.1016/j.chb.2018.09.005

7. Ractham, P., Kaewkitipong, L., \& Firpo, D. (2012). The use of Facebook in an introductory MIS course: Social constructivist learning environment. Decision Sciences Journal of Innovative Education, 10(2), $165-188$.

8. Lampe, C., Wohn, D. Y., Vitak, J., Ellison, N. B., \& Wash, R. (2011). Student use of Facebook for organizing collaborative classroom activities. International Journal of Computer-Supported Collaborative Learning, 6(3), 329-347.

9. Junco, R. (2012). The relationship between frequency of Facebook use, participation in Facebook activities, and student engagement. Computers \& Education, 58(1), 162-171. https://doi.org/10.1016/j.compedu.2011.08.004

10. Smith, E. E. (2016). "A real double-edged sword:" Undergraduate perceptions of social media in their learning. Computers \& Education, 103, 44-58.

11. Kwok, R. C. W., \& Ma, J. (1999). Use of a group support system for collaborative assessment. Computers \& Education, 32(2), 109-125.

12. Yeh, Y. C., Huang, L. Y., \& Yeh, Y. L. (2011). Knowledge management in blended learning: Effects on professional development in creativity instruction. Computers \& Education, 56(1), 146156.

13. Yu, A. Y., Tian, S. W., Vogel, D., \& Kwok, R. C. W. (2010). Can learning be virtually boosted? An investigation of online social networking impacts. Computers \& Education, 55(4), 1494-1503. https://doi.org/10.1016/j.compedu.2010.06.015

14. Lantz-Andersson, A., Vigmo, S., \& Bowen, R. (2013). Crossing boundaries in Facebook: Students' framing of language learning activities as extended spaces. International Journal of ComputerSupported Collaborative Learning, 8(3), 293-312.

15. Hurt, N. E., Moss, G. S., Bradley, C. L., Larson, L. R., Lovelace, M., Prevost, L. B., . . . Camus, M. S. (2012). The 'Facebook'effect: College students' perceptions of online discussions in the age of social networking. International Journal for the Scholarship of Teaching and Learning, 6(2), 1-24.

16. Al-Rahmi, W. M., Alias, N., Othman, M. S., Marin, V. I., \& Tur, G. (2018). A model of factors affecting learning performance through the use of social media in Malaysian higher education. Computers \& Education, 121, 59-72.

17. Molinillo, S., Anaya-Sánchez, R., Aguilar-Illescas, R., \& Vallespín-Arán, M. (2018). Social media-based collaborative learning: Exploring antecedents of attitude. The Internet and Higher Education, 38, 1827.

https://doi.org/10.1016/j.iheduc.2018.04.003

18. Topu, F. B., \& Goktas, Y. (2018). The effects of guidedunguided learning in 3D virtual environment on students' engagement and achievement. Computers in Human Behavior.

19. Liu, M., Liu, L., \& Liu, L. (2018). Group awareness increases student engagement in online collaborative writing. The Internet and Higher Education, 38, 1-8.

20. Sánchez, R. A., Cortijo, V., \& Javed, U. (2014). Students' perceptions of Facebook for academic purposes. Computers \& Education, 70, 138-149.

21. Lin, G. Y. (2018). Anonymous versus identified peer assessment via a Facebook-based learning application: Effects on quality of peer feedback, perceived learning, perceived fairness, and attitude toward the system. Computers \& Education, 116, 81-92. https://doi.org/10.1016/j.compedu.2017.08.010

22. Keles, E. (2018). Use of Facebook for the Community Services Practices course: Community of inquiry as a theoretical framework. Computers \& Education, $116,203-224$.

23. Lin, H. M., \& Tsai, C. C. (2011). College students' conceptions of learning management: The difference between traditional (face-to-face) instruction and Web-based learning environments. Learning, Media and Technology, 36(4), 437-452.

24. Thoms, B., \& Eryilmaz, E. (2014). How media choice affects learner interactions in distance learning classes. Computers \& Education, 75, 112-126

25. Manca, S., \& Ranieri, M. (2013). Is it a tool suitable for learning? A critical review of the literature on Facebook as a technology $\square$ enhanced learning environment. Journal of Computer Assisted Learning, 29(6), 487-504. https://doi.org/10.1111/jcal.12007

26. McCarthy, J. (2012). International design collaboration and mentoring for tertiary students through Facebook. 28(5), 755-775. https://doi.org/10.14742/ajet.1383

27. Schwarz, B., \& Caduri, G. (2016). Novelties in the use of social networks by leading teachers in their classes. Computers \& Education, 102, 35-51.

28.LaRue, E. M. (2012). Using Facebook as course management software: A case study. Teaching and Learning in Nursing, 7(1), 17-22.

29. Chang, W. L., \& Lee, C. Y. (2013). Trust as a learning facilitator that affects students' learning performance in the Facebook community: An investigation in a business planning writing course. Computers \& Education, 62, 320-327. 
30. Wang, M., Cheng, B., Chen, J., Mercer, N., \& Kirschner, P. A. (2017). The use of web-based collaborative concept mapping to support group learning and interaction in an online environment. The Internet and Higher Education, 34, 28-40.

https://doi.org/10.1016/j.iheduc.2017.04.003

31. Wang, R., Scown, P., Urquhart, C., \& Hardman, J. (2014). Tapping the educational potential of Facebook: Guidelines for use in higher education. Education and Information Technologies, 19(1), 2139.

32. Chickering, A. W., \& Ehrmann, S. C. (1996). Implementing the seven principles: Technology as lever. AAHE bulletin, 49, 3-6.

33. Oliver, R. L. (1980). A cognitive model of the antecedents and consequences of satisfaction decisions. Journal of marketing research, 17(4), 460-469.

34, Bhattacherjee, A., \& Premkumar, G. (2004). Understanding changes in belief and attitude toward information technology usage: A theoretical model and longitudinal test. MIS Quarterly, 22(8), 229254.

https://doi.org/10.2307/25148634

35. Lankton, N. K., \& McKnight, H. D. (2012). Examining two expectation disconfirmation theory models: Assimilation and asymmetry effects. Journal of the Association for Information Systems, 13(2), 88-115.

36. Chiu, C. M., Hsu, M. H., Sun, S. Y., Lin, T. C., \& Sun, P. C. (2005). Usability, quality, value and e-learning continuance decisions. Computers \& Education, 45(4), 399-416.

37. Kreijns, K., Kirschner, P. A., \& Jochems, W. (2002). The sociability of computer-supported collaborative learning environments. Educational Technology \& Society, 5(1), 8-22.

38. Kreijns, K., Kirschner, P. A., Jochems, W., \& Van Buuren, H. (2007). Measuring perceived sociability of computer-supported collaborative learning environments. Computers \& Education, 49(2), 176192.

39. Koh, E., \& Lim, J. (2012). Using online collaboration applications for group assignments: The interplay between design and human characteristics. Computers \& Education, 59(2), 481-496.

40. Cress, U., \& Kimmerle, J. (2008). A systemic and cognitive view on collaborative knowledge building with wikis. International Journal of ComputerSupported Collaborative Learning, 3(2), 105-122. https://doi.org/10.1007/s11412-007-9035-z

41. Laurillard, D. (2009). The pedagogical challenges to collaborative technologies. International Journal of Computer-Supported Collaborative Learning, 4(1), 5-20.

42. DeLone, W. H., \& McLean, E. R. (1992). Information systems success: The quest for the dependent variable. Information Systems Research, 3(1), 6096.
43. Iivari, J. (2005). An empirical test of the DeLoneMcLean model of information system success. ACM SIGMIS Database, 36(2), 8-27.

44. Petter, S., DeLone, W. H., \& McLean, E. R. (2008). Measuring information systems success: Models, dimensions, measures, and interrelationships. European Journal of Information Systems, 17, 236263. https://doi.org/10.1057/ejis.2008.15

45. Petter, S., DeLone, W. H., \& McLean, E. R. (2012). The past, present, and future of" IS Success". Journal of the Association for Information Systems, 13(5), 341.

46. Petter, S., DeLone, W. H., \& McLean, E. R. (2013). Information systems success: The quest for the independent variables. Journal of Management Information Systems, 29(4), 7-62.

47. Petter, S., \& McLean, E. R. (2009). A meta-analytic assessment of the DeLone and McLean IS success model: An examination of IS success at the individual level. Information \& Management, 46(3), 159-166. https://doi.org/10.1016/j.im.2008.12.006

48. Scott, M., DeLone, W. H., \& Golden, W. (2016). Measuring eGovernment success: A public value approach. European Journal of Information Systems, 25(3), 187-208.

49. Wang, Y. S. (2008). Assessing e $\square$ commerce systems success: a respecification and validation of the DeLone and McLean model of IS success. Information Systems Journal, 18(5), 529-557.

50. William, H. D., \& Ephraim, R. M. (2003). The DeLone and McLean model of information systems success: A ten-year update. Journal of Management Information Systems, 19(4), 9-30.

51. William, H. D., \& Ephraim, R. M. (2016). Information systems success measurement. Foundations and Trends® in Information Systems, 2(1), 1-116. https://doi.org/10.1561/2900000005

51. Bradley, R. V., Pridmore, J. L., \& Byrd, T. A. (2006). Information systems success in the context of different corporate cultural types: An empirical investigation. Journal of Management Information Systems, 23(2), 267-294.

52. Sabherwal, R. (1999). The relationship between information system planning sophistication and information system success: An empirical assessment. Decision Sciences, 30(1), 137-167.

53. Byrd, T. A., \& Turner, D. E. (2000). Measuring the flexibility of information technology infrastructure: Exploratory analysis of a construct. Journal of Management Information Systems, 17(1), 167-208.

54. Stutzman, F. (2006). Our lives, our facebooks. Paper presented at the 26th INSNA conference, in Vancouver, Canada

55. Chiu, C. M., Chiu, C. S., \& Chang, H. C. (2007). Examining the integrated influence of fairness and quality on learners' satisfaction and Web $\square$ based learning continuance intention. Information Systems Journal, 17(3), 271-287. 
56. Liaw, S. S. (2008). Investigating students' perceived satisfaction, behavioral intention, and effectiveness of e-learning: A case study of the Blackboard system. Computers \& Education, 51(2), 864-873.

57. Spreng, R. A., MacKenzie, S. B., \& Olshavsky, R. W. (1996). A Reexamination of the Determinants of Consumer Satisfaction. Journal of Marketing, 60(3), 15-32. doi:10.2307/1251839

58. Bhattacherjee, A. (2001). Understanding information systems continuance: An expectation-confirmation model. MIS Quarterly, 25(3), 351-370.

59. Chang, Y. P., \& Zhu, D. H. (2012). The role of perceived social capital and flow experience in building users' continuance intention to social networking sites in China. Computers in Human Behavior, 28(3), 9951001.

60. Chen, S. C., Chen, H. H., \& Chen, M. F. (2009). Determinants of satisfaction and continuance intention towards self-service technologies. Industrial Management \& Data Systems, 109(9), 1248-1263. https://doi.org/10.1108/02635570911002306

61. Chen, S. C., Yen, D. C., \& Hwang, M. I. (2012). Factors influencing the continuance intention to the usage of Web 2.0: An empirical study. Computers in Human Behavior, 28(3), 933-941.

62. Joo, Y. J., Park, S., \& Shin, E. K. (2017). Students' expectation, satisfaction, and continuance intention to use digital textbooks. Computers in Human Behavior, 69, 83-90.

63. Joo, Y. J., So, H. J., \& Kim, N. H. (2018). Examination of relationships among students' self-determination, technology acceptance, satisfaction, and continuance intention to use K-MOOCs. Computers \& Education.

64. Lee, M. C. (2010). Explaining and predicting users' continuance intention toward e-learning: An extension of the expectation-confirmation model. Computers \& Education, 54(2), 506-516.

65. Roca, J. C., Chiu, C. M., \& Martínez, F. J. (2006). Understanding e-learning continuance intention: An extension of the Technology Acceptance Model. International Journal of Human-Computer Studies, 64(8), 683-696. https://doi.org/10.1016/j.ijhcs.2006.01.003

66. Zhao, L., \& Lu, Y. (2012). Enhancing perceived interactivity through network externalities: An empirical study on micro-blogging service satisfaction and continuance intention. Decision Support Systems, 53(4), 825-834.

67. Zhao, L., Lu, Y., Zhang, L., \& Chau, P. Y. K. (2012). Assessing the effects of service quality and justice on customer satisfaction and the continuance intention of mobile value-added services: An empirical test of a multidimensional model. Decision Support Systems, 52(3), 645-656.

68. Zhou, T. (2013). An empirical examination of continuance intention of mobile payment services. Decision Support Systems, 54(2), 1085-1091. https://doi.org/10.1016/j.dss.2012.10.034

69. Ajjan, H., \& Hartshorne, R. (2008). Investigating faculty decisions to adopt Web 2.0 technologies: Theory and empirical tests. The Internet and Higher Education, 11(2), 71-80. https://doi.org/10.1016/j.iheduc.2008.05.002

70. Ajzen, I. (1991). The theory of planned behavior. Organizational Behavior and Human Decision Processes, 50(2), 179-211.

71. Ajzen, I., \& Fishbein, M. (1980). Understanding attitudes and predicting behavior. Englewood Cliffs, NJ: Prentice Hall.

72. Davis, F. D. (1989). Perceived usefulness, perceived ease of use, and user acceptance of information technology. MIS Quarterly, 13(3), 319-340. https://doi.org/10.2307/249008

73. Taylor, S., \& Todd, P. A. (1995). Understanding information technology usage: A test of competing models. Information Systems Research, 6(2), 144176.

74. Venkatesh, V., \& Davis, F. D. (2000). A theoretical extension of the technology acceptance model: Four longitudinal field studies. Management Science, 46(2), 186-204.

75. Venkatesh, V., Morris, M. G., Davis, G. B., \& Davis, F. D. (2003). User acceptance of information technology: Toward a unified view. MIS Quarterly, 27(3), 425-478. https://doi.org/10.2307/30036540

76. Ringle, C. M., Wende, S., \& Becker, J. M. (2015). SmartPLS 3. Boenningstedt: SmartPLS GmbH, http://www. smartpls. com.

77. Hair, J. F., Hult, G. M., Ringle, C., \& Sarstedt, M. (2013). A Primer on Partial Least Squares Structural Equation Modeling (PLS-SEM). Los Angeles, CA: Sage Publications.

78. Kline, R. B. (2011). Convergence of structural equation modeling and multilevel modeling: na.

79. Joinson, A. N. (2008). Looking at, looking up or keeping up with people?: Motives and use of Facebook. Paper presented at the Proceedings of the SIGCHI conference on Human Factors in Computing Systems, New York. https://doi.org/10.1145/1357054.1357213 
Timothy McBush Hiele et al., International Journal of Advanced Trends in Computer Science and Engineering, 8(1.5), 2019, 375- 386

Appendix: Research items

\begin{tabular}{|c|c|c|c|}
\hline Construct & Items & & Sources \\
\hline \multirow{9}{*}{ Sociability } & SO1 & $\begin{array}{l}\text { Facebook enables me } \\
\text { to easily contact my } \\
\text { teammates. }\end{array}$ & \multirow{9}{*}{$\begin{array}{l}\text { (Koh \& } \\
\text { Lim, 2012; } \\
\text { Kreijns et } \\
\text { al., 2007) }\end{array}$} \\
\hline & $\mathrm{SO} 2$ & $\begin{array}{l}\text { Facebook enables me } \\
\text { to get a good } \\
\text { impression of my } \\
\text { teammates. }\end{array}$ & \\
\hline & SO3 & $\begin{array}{l}\text { Facebook allows } \\
\text { spontaneous informal } \\
\text { conversations. }\end{array}$ & \\
\hline & $\mathrm{SO} 4$ & $\begin{array}{l}\text { Facebook enables us } \\
\text { to develop into a well } \\
\text { performing team. }\end{array}$ & \\
\hline & SO6 & $\begin{array}{l}\text { Facebook enables me } \\
\text { to develop good } \\
\text { work relationships } \\
\text { with my teammates. } \\
\text { Facebook enables me } \\
\text { to identify myself } \\
\text { with the team. }\end{array}$ & \\
\hline & SO7 & $\begin{array}{l}\text { I feel comfortable } \\
\text { with Facebook }\end{array}$ & \\
\hline & SO8 & $\begin{array}{l}\text { Facebook allows for } \\
\text { non-task related } \\
\text { conversations. }\end{array}$ & \\
\hline & SO9 & $\begin{array}{l}\text { Facebook enables me } \\
\text { to make close } \\
\text { friendships with my } \\
\text { teammates. }\end{array}$ & \\
\hline & SO10 & $\begin{array}{l}\text { Facebook is visible } \\
\text { to other Internet } \\
\text { users as members of } \\
\text { the public can view } \\
\text { my work on the } \\
\text { system. }\end{array}$ & \\
\hline \multirow{7}{*}{$\begin{array}{l}\text { Facebook } \\
\text { Quality }\end{array}$} & FQ1 & $\begin{array}{l}\text { The layout and user } \\
\text { interface design of } \\
\text { Facebook is friendly. }\end{array}$ & \multirow{7}{*}{$\begin{array}{l}\text { (Bradley et } \\
\text { al., 2006; } \\
\text { Chiu et al., } \\
\text { 2005) }\end{array}$} \\
\hline & FQ2 & $\begin{array}{l}\text { It is easy to navigate } \\
\text { Facebook. }\end{array}$ & \\
\hline & FQ3 & $\begin{array}{l}\text { Facebook provides } \\
\text { the services I need. }\end{array}$ & \\
\hline & FQ3 & $\begin{array}{l}\text { I feel comfortable in } \\
\text { using the functions } \\
\text { and services provided } \\
\text { by Facebook }\end{array}$ & \\
\hline & FQ4 & $\begin{array}{l}\text { Facebook is available } \\
24 \text { hours per day, } \\
\text { seven days per week. }\end{array}$ & \\
\hline & FQ5 & $\begin{array}{l}\text { Facebook response } \\
\text { times are adequate to } \\
\text { keep me satisfied. }\end{array}$ & \\
\hline & FQ6 & $\begin{array}{l}\text { Facebook exhibit } \\
\text { high degrees of } \\
\text { reliability. } \\
\text { Facebook uptimes }\end{array}$ & \\
\hline
\end{tabular}

are comparable to available my time.

I believe Facebook

PF1 can assist my group work effectiveness. I believe Facebook

PF2 can assist my group $\begin{array}{lll}\text { Perceived } & \text { work efficiency. } & \text { (Liaw, } \\ \text { Effectiveness } & \text { I believe Facebook } & \text { 2008) }\end{array}$ $\begin{array}{lll}\text { Perceived } & \text { work efficiency. } & \text { (Liaw, } \\ \text { Effectiveness } & \text { I believe Facebook } & \text { 2008) }\end{array}$ $\begin{array}{lll}\text { Effectiveness } & \text { I believe Facebook } \\ & \text { PF3 } & \text { can assist my group }\end{array}$ work performance. I believe Facebook

PF4 can assist my group work motivation.

\begin{tabular}{|c|c|c|c|}
\hline Satisfaction & SF2 & $\begin{array}{l}\text { In general, I am } \\
\text { satisfied with the } \\
\text { performance of } \\
\text { Facebook while I am } \\
\text { working on my group } \\
\text { projects. } \\
\text { In General, I am } \\
\text { pleased with the } \\
\text { experience of using } \\
\text { Facebook while I am } \\
\text { working on my group } \\
\text { projects. }\end{array}$ & $\begin{array}{l}\text { (Chiu et al., } \\
2005 \text { ) }\end{array}$ \\
\hline $\begin{array}{l}\text { Attitude } \\
\text { toward } \\
\text { Facebook }\end{array}$ & AF4 & $\begin{array}{l}\text { Using Facebook is a } \\
\text { good idea. } \\
\text { Facebook makes } \\
\text { work more } \\
\text { interesting. } \\
\text { Working with } \\
\text { Facebook is fun. } \\
\text { I like working with } \\
\text { Facebook. }\end{array}$ & $\begin{array}{l}\text { (Venkatesh } \\
\text { et al., 2003) }\end{array}$ \\
\hline $\begin{array}{l}\text { Continuance } \\
\text { Intention }\end{array}$ & CF1 & $\begin{array}{l}\text { I intend to continue } \\
\text { using Facebook for } \\
\text { doing group projects } \\
\text { in the future. } \\
\text { I will continue using } \\
\text { Facebook for doing } \\
\text { group projects in the } \\
\text { future. } \\
\text { I will regularly use } \\
\text { Facebook for doing } \\
\text { group projects in the } \\
\text { future. }\end{array}$ & $\begin{array}{l}\text { (Chiu et al., } \\
2005 \text { ) }\end{array}$ \\
\hline
\end{tabular}

